\title{
APPLICATIONS OF LOW ENTHALPY GEOTHERMAL ENERGY: THE CASE OF THE FACULTY OF PHYSICAL AND MATHEMATICAL SCIENCES AT THE UNIVERSITY OF CHILE
}

\author{
CLAUDIA MAC-LEAN, REYNALDO CABEZAS, MAURICIO MUÑOZ \& LUIS VARGAS \\ Faculty of Physical and Mathematical Sciences, University of Chile, Chile.
}

\begin{abstract}
In recent decades, the industry has observed a significant shift towards the use of renewable energy, such as solar, wind and geothermal. The Chilean scenario has not been an exception, and much progress has been made in sustainable energy prospection and implementation, especially in the electricity sector, where solar and wind power amount $2300 \mathrm{MW}$, and since April 2017, the first geothermal power plant $(48 \mathrm{MW})$ has come into operation. In the area of low enthalpy geothermal energy, the use is around $19 \mathrm{MW}$.

The Faculty of Physical and Mathematical Sciences at the University of Chile has been contributing to this transformational process, with its Sustainable Campus initiative. The first step of this initiative is the introduction of renewable energy on site, which has been achieved through the installation of a solar photovoltaic plant of $15 \mathrm{~kW}$. Along this line, the design and implementation of a geothermal air conditioning system (HAVC) is underway, which will serve the classrooms and offices in the traditional engineering building of the campus. The technology to be used in this project is the Ground Heat Pump (GHP).

The present paper includes an introduction of the applications of low enthalpy geothermal energy in Chile, a description of the Office of Engineering for Sustainable Development at the Faculty of Physical and Mathematical Sciences, and the design of a geothermal HAVC system in the university campus, considering economic, environmental, technical and social aspects. Besides the operation of the GHP, the system will be used for teaching purposes to incorporate sustainable development in the curriculum of the university. The expected savings of the geothermal system versus an aerothermal design are $41,070 \mathrm{kWh}$ annually, considering both cooling and heating.

Keywords: Geothermal energy, renewable energy, sustainable university campus.
\end{abstract}

\section{INTRODUCTION}

Geothermal Heat Pumps (GHP) systems are one of the fastest growing renewable technologies in the world, with most of this growth happening in China, USA and Europe. The number of GHP increased $\sim 10 \%$ annually between 2010 and 2015. By the end of 2015, the global installed capacity was estimated at almost 50,258 GWth with an annual energy use of 326,848 TJ/year. This represents $70.9 \%$ of installed capacity and $55.15 \%$ of the use of direct uses of geothermal energy [1].

Santiago is the Chilean capital city, where more than 6.5 million inhabitants are living. The city has pollution problems, which are increased in winter time by the use of conventional heating systems that produce emissions and particulate matter. On the other hand, in summer time, temperature reaches up to $30-35^{\circ} \mathrm{C}$ and therefore, cooling systems are required. Typical Santiago building cooling systems have low efficiency and high costs of operation and maintenance.

In this work, the use of GHP is proposed for heating and cooling a building in the Faculty of Physical and Mathematical Sciences (FCFM for its acronym in Spanish) at the University of Chile. The GHP is operated with electricity and therefore there is no direct emissions of 
particulate matter or greenhouse gases during the system functioning. The GHP concentrates and transports heat from the ground to the building, and vice versa, for heating and cooling purposes. This technology represents savings of $25-50 \%$ over air source heat pumps [2].

Due to the excellent aquifer features at the FCFM, an open loop system is proposed to feed the Ground Water Heat Pump (GWHP). Operation of a GWHP consists of extracting groundwater to exchange heat and, subsequently, the water is re-injected into the aquifer [3].

In Chile, geothermal heat pumps are scarce because of the lack of knowledge of the benefits of this type of heating and cooling system, and high initial investment due to drilling or excavation costs. However, as background for the proposed system at the FCFM, similar case studies in the international and national context are summarized in the following table.

To carry out the analysis of technical and economic sustainability, the operation of this heating and cooling system is modelled for a section of a building at the FCFM. The performance of this system is compared against a standard aerothermal HAVC system in order to show the savings of the geothermal solution. This case is expected to promote the use of this technology for similar buildings on campus.

\section{ENERGY NEEDS AND PROJECT METHODOLOGY}

\subsection{Energy needs at university campus}

Founded in 1842, the University of Chile is the main and oldest institution of higher education owned by the State in Chile, with a national and public character. It is a research-oriented institution, and it is organised in 14 faculties.

The FCFM, in which our work is focused, hosts the School of Engineering. It has 425 professors, 1100 graduate students and 4860 undergraduate students.

Table 1: International and National Similar Projects.

\begin{tabular}{|c|c|c|}
\hline Place & Brief description & Capacity \\
\hline Bonn, Germany & 20 households & $\begin{array}{l}450 \mathrm{~kW} \text { of heating capacity from } \\
\text { underground water }\end{array}$ \\
\hline Frankfurt, Germany & Building with offices & $1 \mathrm{MW}$ heating, 4 wells \\
\hline Bonn, Germany & United Nations Campus & 4.5 MW, 3 wells \\
\hline Baku, Azerbaiyán & $\begin{array}{l}\text { Diplomatic Academy of } \\
\text { Azerbaiyán, heating and cooling }\end{array}$ & $\begin{array}{l}2000 \mathrm{~kW} \text { heat, } 1200 \mathrm{~kW} \text { cold, } \\
290 \times 140 \mathrm{~m} \text { of geothermal probes }\end{array}$ \\
\hline Dortmund, Germany & $\begin{array}{l}\text { Buildings with offices, heating } \\
\text { and cooling }\end{array}$ & $800 \mathrm{~kW}$ heat, $600 \mathrm{~kW}$ cold \\
\hline Cologne, Germany & $\begin{array}{l}\text { 'KidZ' service centre, heating } \\
\text { and cooling }\end{array}$ & $150 \mathrm{~kW}$, underground water used \\
\hline Linz, Austria & $\begin{array}{l}\text { Sports centre, heating and } \\
\text { cooling }\end{array}$ & $\begin{array}{l}170 \mathrm{~kW}, 26 \times 100 \mathrm{~m} \text { of geothermal } \\
\text { probes }\end{array}$ \\
\hline Quelen Hotel, Chile & $\begin{array}{l}\text { Heating and cooling system for } \\
\text { the building }\end{array}$ & $\begin{array}{l}40 \mathrm{~kW} \text { with a Coefficient of Per- } \\
\text { formance COP of } 5\end{array}$ \\
\hline $\begin{array}{l}\text { Hermanita de los } \\
\text { pobres residencie, } \\
\text { Chile }\end{array}$ & Heating of a residence for adults & $\begin{array}{l}100 \mathrm{~kW} \text { with a Coefficient of } \\
\text { Performance COP of } 4\end{array}$ \\
\hline
\end{tabular}


In terms of energy consumption of the FCFM, it is relevant to present certain preliminary information, in order to start dimensioning the challenge and the project itself. In 2015, the campus spent $7.6 \mathrm{GWh}$ of electricity which represents approximately USD\$ 1 million. Figure 1 shows the electric grid of the campus.

In terms of consumption, the main areas are heating, ventilation and air conditioning (HVAC), informatics, lighting, labs, and others. The share of this demand is shown in Fig. 2.

Specifically, the informatics consumption is composed of $50 \%$ by servers and $50 \%$ by desktop computers. In terms of lightening, $80 \%$ of it is by fluorescent tubes on campus. This consumption contemplates seven buildings, one of which is the 'Edificio Escuela', where the geothermal system for heating and cooling is proposed.

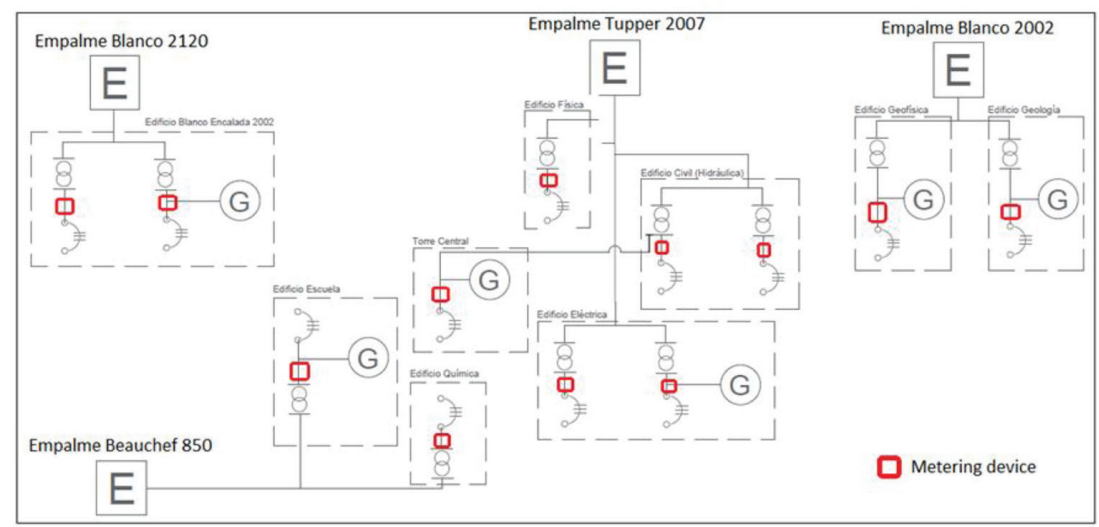

Figure 1: Electric grid and connecting points at the FCFM.

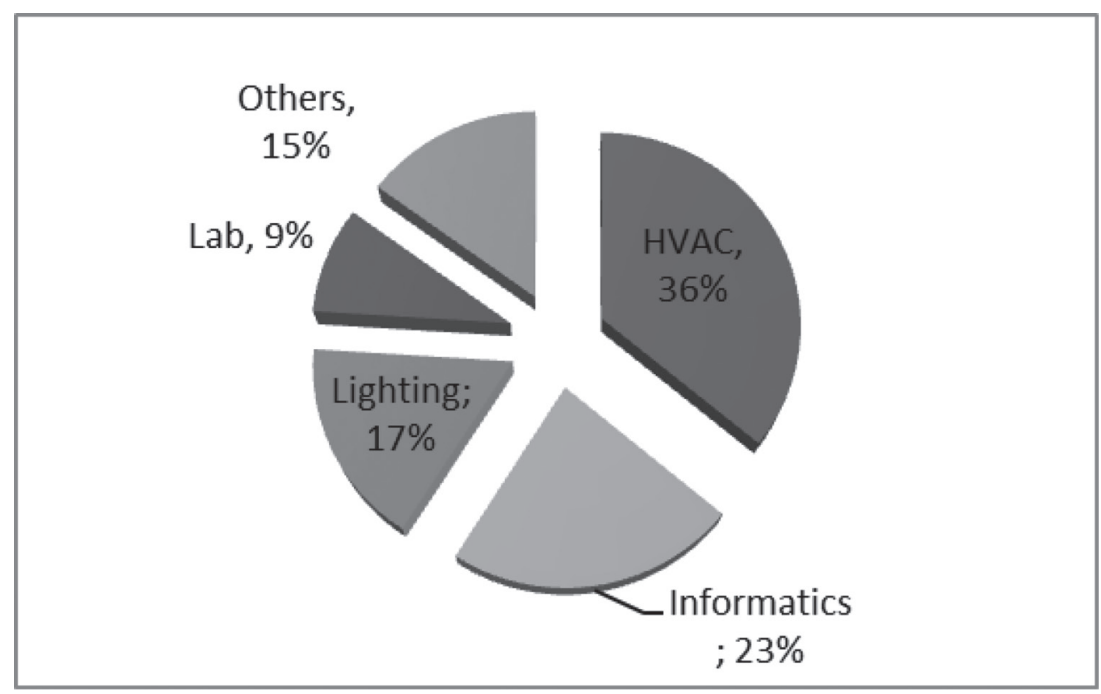

Figure 2: Electric consumption of the FCFM. 


\subsection{Methodology}

Regarding the typical analysis for heating and cooling systems with geothermal heat pump (4), the methodology to undertake this project has the following stages:

A. Estimation of the heating and cooling loads, taking into account local exterior temperature, comfort temperature of the classrooms and offices in the building, design features of the building, air renovations and solar gains.

B. Estimation of thermal energy usage based on heating and cooling loads and hours used throughout a year.

C. Determine wells requirements based on groundwater flow to guarantee nominal function conditions of the water to the heat pump.

In the next section, the methodology steps for the project are presented.

\section{PROJECT DESCRIPTION AND RESULTS}

\subsection{Estimation of heating and cooling loads}

The main heating and cooling loads of this project maybe classified in six categories:

3.1.1 Outside temperature and comfort temperature inside the building

A key element to calculate the thermal demands, are the temperatures in the zone where the system is to be installed. Typically, minimum and maximum temperatures are considered. In the present study, data is used from 'La Platina' meteorological station, taken with $1 \mathrm{~h}$ of difference between years 2012 and 2015. Data shows that the minimum temperature in winter time is $\sim 1^{\circ} \mathrm{C}$ and maximum temperature in summer time is $\sim 32^{\circ} \mathrm{C}$. In addition, daily thermal amplitude is $\sim 10^{\circ} \mathrm{C}$ in winter time and $\sim 15^{\circ} \mathrm{C}$ in summer time (Fig. 3).

The maximum temperature in the day is a round 14:00 and 16:00 h, when the building is used at full capacity. On the other hand, the minimum between 04:00 and 06:00, when only

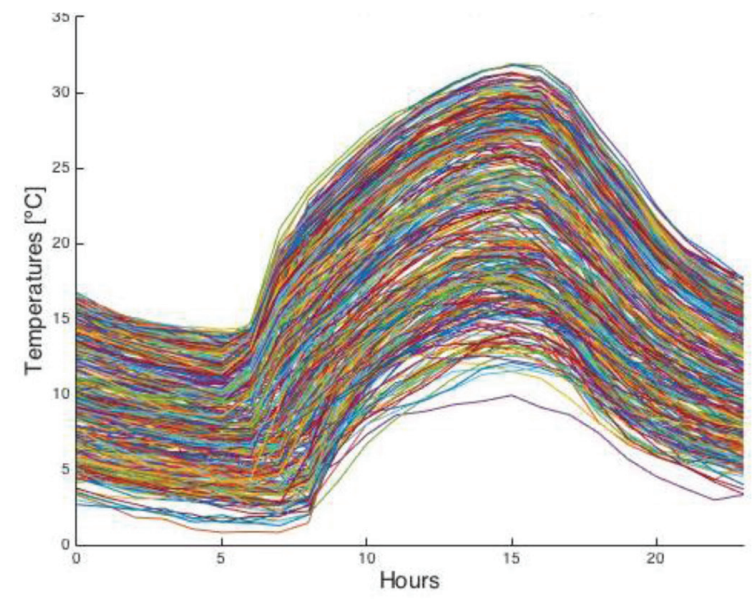

Figure 3: Daily temperatures in a typical year in Santiago, Chile (average of the years 20122015). 
the security staff is at the campus. For heating and cooling purposes, the inside temperature for the building is defined as $24^{\circ} \mathrm{C}$ and $20^{\circ} \mathrm{C}$, respectively.

3.1.2 Identification of the places (classrooms, offices, halls) to be intervened and their global heat transfer coefficient

The current heating and cooling systems in the building to be intervened 'Edificio Escuela' is an air source heat pump used only for cooling purposes (model 20 GTN 080), which dates from 1996 and some of them correspond to isolated heating electric devices. The heating/ cooling devices are 12 air handlers with an electric heating source and 5 fancoils. Such equipment provides services for several classrooms, offices, and an auditorium. All are located in the south sector of the 'Edificio Escuela'.

The present projects aims at modernising these installations, and additionally integrate new areas, in order to provide heating and cooling for all the classrooms and offices located in the south part of the 'Edificio Escuela'. The main clients include 10 classrooms and several offices.

The size and dimensions of the different zones to be heated and cooled by the geothermal heat pump (comprising classrooms and offices) are detailed in Table 2. The heat transfer

Table 2: Heat transfer coefficient for offices and classrooms to be intervened, according to their size, materials and heat transfer coefficient (U), considering error for measuring

\begin{tabular}{|c|c|c|c|c|c|}
\hline Classroom/office & $\begin{array}{l}\text { Window } \\
{\left[\mathrm{m}^{2}\right]}\end{array}$ & $\begin{array}{l}\text { Wall } \\
{\left[\mathbf{m}^{2}\right]}\end{array}$ & $\begin{array}{l}\text { UA window } \\
{[\mathbf{W} / \mathbf{K}]}\end{array}$ & $\begin{array}{l}\text { UA wall } \\
{[\mathbf{W} / \mathbf{K}]}\end{array}$ & $\begin{array}{l}\text { UA total } \\
{[\mathrm{W} / \mathrm{K}]}\end{array}$ \\
\hline S14 & $24.2 \pm 0.3$ & $48.5 \pm 0.3$ & $132.8 \pm 7.8$ & $121.1 \pm 12.9$ & $254.0 \pm 20.7$ \\
\hline S15 & $28.5 \pm 0.3$ & $94.8 \pm 0.3$ & $156.7 \pm 8.8$ & $236.9 \pm 24.5$ & $393.6 \pm 33.4$ \\
\hline S16 & $8.1 \pm 0.3$ & $14.4 \pm 0.3$ & $44.3 \pm 3.7$ & $35.9 \pm 4.4$ & $80.2 \pm 8.2$ \\
\hline S17 & $12.8 \pm 0.3$ & $33.1 \pm 0.3$ & $70.5 \pm 4.9$ & $82.7 \pm 9.1$ & $153.2 \pm 14.0$ \\
\hline S18 & $8.1 \pm 0.3$ & $14.4 \pm 0.3$ & $44.3 \pm 3.7$ & $35.9 \pm 4.4$ & $80.2 \pm 8.2$ \\
\hline S19 & $28.5 \pm 0.3$ & $94.4 \pm 0.3$ & $156.7 \pm 8.8$ & $235.9 \pm 24.4$ & $392.6 \pm 33.3$ \\
\hline Treasury & $16.1 \pm 0.3$ & $33.6 \pm 0.3$ & $88.7 \pm 5.8$ & $84.0 \pm 9.2$ & $172.7 \pm 15.0$ \\
\hline $\mathrm{S} 24$ & $20.7 \pm 0.3$ & $51.9 \pm 0.3$ & $113.9 \pm 6.9$ & $129.8 \pm 13.8$ & $243.6 \pm 20.7$ \\
\hline S25 & $24.4 \pm 0.3$ & $98.8 \pm 0.3$ & $134.3 \pm 7.8$ & $247.1 \pm 25.5$ & $381.4 \pm 33.4$ \\
\hline S26 & $11.0 \pm 0.3$ & $38.7 \pm 0.3$ & $60.4 \pm 4.5$ & $96.7 \pm 10.5$ & $157.1 \pm 15.0$ \\
\hline S27 & $7.0 \pm 0.3$ & $18.2 \pm 0.3$ & $38.4 \pm 3.5$ & $45.6 \pm 5.4$ & $84.0 \pm 8.9$ \\
\hline S28 & $24.4 \pm 0.3$ & $98.4 \pm 0.3$ & $134.3 \pm 7.8$ & $246.1 \pm 25.4$ & $380.4 \pm 33.3$ \\
\hline S29 & $10.5 \pm 0.3$ & $47.0 \pm 0.3$ & $57.8 \pm 4.4$ & $117.6 \pm 12.6$ & $175.3 \pm 16.9$ \\
\hline Summer School & $13.8 \pm 0.3$ & $35.3 \pm 0.3$ & $75.9 \pm 5.2$ & $88.4 \pm 9.7$ & $164.3 \pm 14.8$ \\
\hline S30 & $0.0 \pm 0.0$ & $48.3 \pm 0.0$ & $0.0 \pm 0.0$ & $120.7 \pm 12.9$ & $120.7 \pm 12.9$ \\
\hline Off. $13^{\text {rd }}$ Floor & $10.1 \pm 0.3$ & $38.2 \pm 0.3$ & $55.7 \pm 4.3$ & $95.6 \pm 10.4$ & $151.3 \pm 14.6$ \\
\hline Off. $23^{\text {rd }}$ Floor & $3.9 \pm 0.3$ & $5.1 \pm 0.3$ & $21.5 \pm 2.7$ & $12.8 \pm 2.1$ & $34.2 \pm 4.8$ \\
\hline Off. $33^{\text {rd }}$ Floor & $7.8 \pm 0.3$ & $11.7 \pm 0.3$ & $42.9 \pm 3.7$ & $29.1 \pm 3.7$ & $72.0 \pm 7.4$ \\
\hline Off. $43^{\text {rd }}$ Floor & $5.1 \pm 0.3$ & $5.4 \pm 0.3$ & $28.2 \pm 3.0$ & $13.6 \pm 2.2$ & $41.8 \pm 5.2$ \\
\hline Off. $53^{\text {rd }}$ Floor & $10.2 \pm 0.3$ & $38.4 \pm 0.3$ & $55.9 \pm 4.3$ & $95.9 \pm 10.4$ & $151.8 \pm 14.7$ \\
\hline
\end{tabular}


coefficient (U) for window and walls are equal to $5.5 \pm 0.25\left[\mathrm{~W} / \mathrm{m}^{2} \mathrm{~K}\right]$ and $2.5 \pm 0.25$ [W/ $\mathrm{m}^{2} \mathrm{~K}$, respectively.

The global heat transfer coefficient for all the classrooms and offices yields a value of $3,684 \pm 335[\mathrm{~kW} / \mathrm{K}]$.

\subsubsection{Transmission loads}

The transmission loads contain all the heat losses or gains associated with the conduction and convection through the building surrounding. Transmission loads are calculated with the following equation:

$$
Q_{t}=\sum_{j} U \cdot \Delta T
$$

where $\mathrm{U}$ is the global heat transference coefficient $[\mathrm{kW} / \mathrm{K}], \Delta T$ is temperature difference between the outside and the comfort temperature for heating and cooling purposes. Transmission loads for summer and winter time are depicted in Fig. 4.

\subsubsection{Air renovations loads}

Thermal loads are those related to air renovations and subsequently are gain or losses if outside temperature is higher or lower than comfort temperature. It is determined by the following equation:

$$
Q_{v}=\rho \cdot C_{p} \cdot \dot{V} \cdot \Delta T
$$

where $\rho$ is air density $\left(1,2\left[\mathrm{~kg} / \mathrm{m}^{3}\right]\right), C_{p}$ is the air specific heat $\left(1.005\left[\mathrm{~J} / \mathrm{kg} \cdot{ }^{\circ} \mathrm{C}\right]\right)$, and $\dot{V}$ is air volumetric flow $(5[\mathrm{~L} / \mathrm{s}]$ per person). Figure 5 shows the thermal ventilation loads in a typical summer day (blue) and winter day (red). The negative values mean heat losses and the positive values indicate heat gains. It is considered that the ventilation systems work from 08:00 to $19: 00 \mathrm{~h}$ and are used at $70 \%$ capacity.

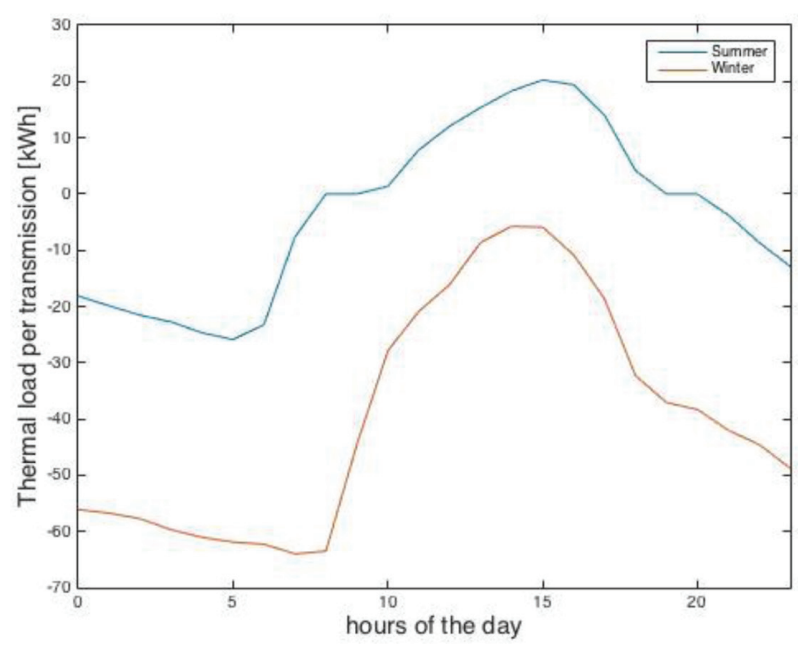

Figure 4: thermal transmission loads in a typical summer day (blue) and winter (red) (average of the years 2012-2015). 


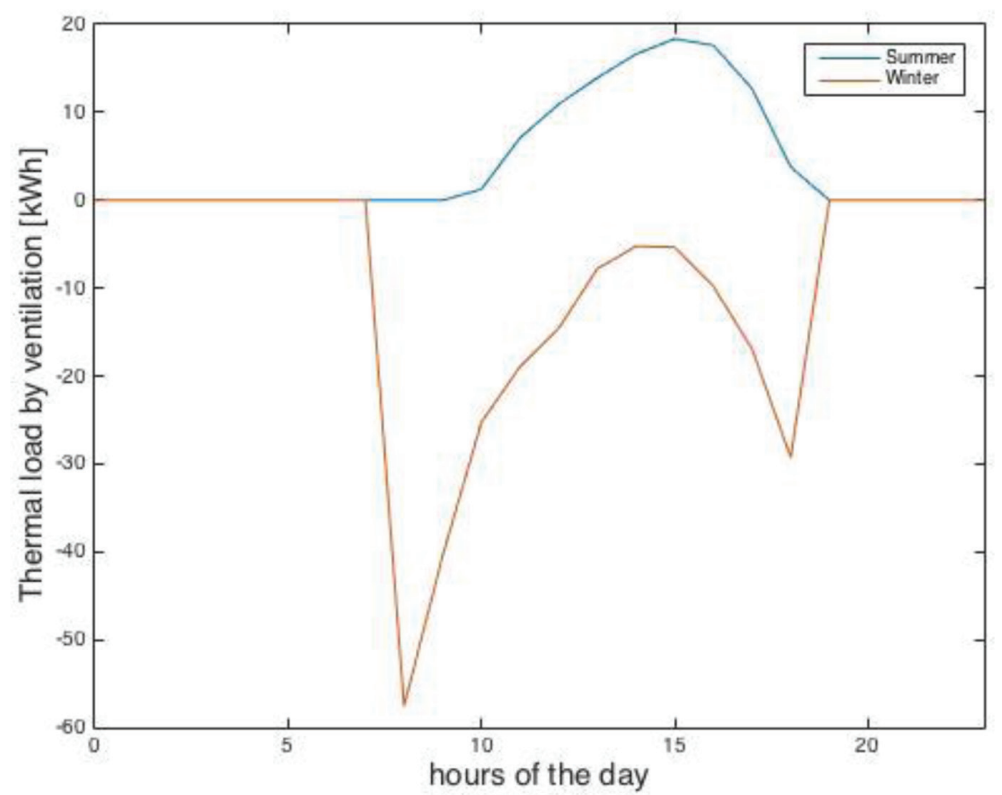

Figure 5: Air renovation loads in a typical summer day (blue) and winter (red), considering that the students are in university between 08:00 and 19:00 $\mathrm{h}$ (average of the years 2012-2015).

3.1.5 Internal gains for people and equipment

In the classrooms was considered: 1 projector (200 [W]), 1 computer $(300[\mathrm{~W}])$, and all of lightening in each place. For the offices was consider 10 computers of 300 [W] and 96 lightening of 60 [W]. The working hours are from 08:00 to 19:00 h. The results are an amount of $15.2[\mathrm{kWh}]$ energy per hour of internal gains.

In terms of internal gains from people, an average person releases an estimate of 100 [W]. The maximum capacity between 08:00 and 19:00 is approximately 700 people. We consider in the range of $70 \%$ of the maximum capacity, which corresponds to 490 people. Thus, the heat gain is $49[\mathrm{kWh}]$. Year round, the total internal gain is $64.2 \mathrm{kWh} / \mathrm{h}$.

\subsubsection{Solar gains}

Solar gains are related to heating by sun light. For the present estimations since these gains were due to location of the south part of the 'Edificio Escuela', these solar gains are difficult to calculate.

\subsection{Annual energy consumption}

The resulting heating and cooling demand in MWh are summarized in Table 3. In addition, there is an estimation for the electric energy consumption taking into account heating and cooling COP (coefficient of performance) of geothermal and pumps and air source heat pumps. The operation of an Geothermal Heat Pump (GHP) is characterised by the coefficient of performance defined as the ratio between useful thermal energy E_t [Watt] and electrical energy consumption E_el [Watt]:

$$
\text { COP=E_t/E_el". }
$$


Table 3: Heating and cooling consumption relative to electrical consumption for a throughout a year (average of the years 2012-2015).

\begin{tabular}{|c|c|c|c|c|c|c|}
\hline \multirow[b]{2}{*}{ Month } & \multirow{2}{*}{$\begin{array}{l}\text { Heating } \\
\text { consumption } \\
\mathbf{M W h}_{\text {thermal }}\end{array}$} & $\begin{array}{l}\text { Electrical } \\
\text { consumption } \\
(\mathbf{G H P})^{*}\end{array}$ & $\begin{array}{l}\text { Electrical } \\
\text { consumption } \\
(\mathbf{A S H P})^{* *}\end{array}$ & $\begin{array}{l}\text { Cooling } \\
\text { consumption }\end{array}$ & $\begin{array}{l}\text { Electrical } \\
\text { consump- } \\
\text { tion (GHP) }\end{array}$ & $\begin{array}{l}\text { Electrical } \\
\text { consump- } \\
\text { tion } \\
*(\text { ASHP)** }\end{array}$ \\
\hline & & $\mathbf{M W h}_{\text {electrical }}$ & $\mathbf{M W h}_{\text {electrical }}$ & $\mathbf{M W h}_{\text {thermal }}$ & $\mathbf{M W h}_{\text {electrical }}$ & $\mathbf{M W h}_{\text {electrical }}$ \\
\hline 11 & $5.80 \pm 0.52$ & $1.32 \pm 0.12$ & $1.61 \pm 0.14$ & $27.89 \pm 2.51$ & 4.98 & $9.96 \pm 0.90$ \\
\hline Feb & $5.98 \pm 0.54$ & $1.36 \pm 0.12$ & $1.66 \pm 0.15$ & $24.98 \pm 2.25$ & $4.46 \pm 0.40$ & $8.92 \pm 0.80$ \\
\hline Mar & $9.03 \pm 0.81$ & $2.05 \pm 0.18$ & $2.51 \pm 0.23$ & $24.87 \pm 2.24$ & 4.44 & $8.88 \pm 0.80$ \\
\hline Apr & $14.37 \pm 1.29$ & $3.27 \pm 0.29$ & $3.99 \pm 0.36$ & $15.87 \pm 1.43$ & $2.83 \pm 0.25$ & $5.67 \pm 0.51$ \\
\hline May & $19.29 \pm 1.74$ & $4.38 \pm 0.39$ & $5.36 \pm 0.48$ & $9.00 \pm 0.81$ & $1.61 \pm 0.14$ & $3.21 \pm 0.29$ \\
\hline Jun & $23.57 \pm 2.12$ & $5.36 \pm 0.48$ & $6.55 \pm 0.59$ & $4.15 \pm 0.37$ & $0.74 \pm 0.07$ & $1.48 \pm 0.13$ \\
\hline Jul & $26.04 \pm 2.34$ & $5.92 \pm 0.53$ & $7.23 \pm 0.65$ & $2.96 \pm 0.27$ & $0.53 \pm 0.05$ & $1.06 \pm 0.10$ \\
\hline Ago & $22.70 \pm 2.04$ & $5.16 \pm 0.46$ & $6.31 \pm 0.57$ & $4.50 \pm 0.41$ & $0.80 \pm 0.07$ & $1.61 \pm 0.14$ \\
\hline Sep & $17.29 \pm 1.56$ & $3.93 \pm 0.35$ & $4.80 \pm 0.43$ & $7.03 \pm 0.63$ & $1.26 \pm 0.11$ & $2.51 \pm 0.23$ \\
\hline Oct & $14.45 \pm 1.30$ & $3.28 \pm 0.30$ & $4.01 \pm 0.36$ & $13.68 \pm 1.23$ & $2.44 \pm 0.22$ & $4.89 \pm 0.44$ \\
\hline Nov & $10.88 \pm 0.98$ & $2.47 \pm 0.22$ & $3.02 \pm 0.27$ & $19.91 \pm 1.79$ & $3.56 \pm 0.32$ & $7.11 \pm 0.64$ \\
\hline Dec & $8.21 \pm 0.74$ & $1.87 \pm 0.17$ & $2.28 \pm 0.21$ & $24.93 \pm 2.24$ & $4.45 \pm 0.40$ & $8.90 \pm 0.80$ \\
\hline Total & $\mathbf{1 7 7 . 6 1 \pm 1 5 . 9 8}$ & $40.37 \pm 3.63$ & $\mathbf{4 9 . 3 4} \pm 4.44$ & $179.77 \pm 16.18$ & $32.10 \pm 2.89$ & $\mathbf{6 4 . 2 0} \pm 5.78$ \\
\hline
\end{tabular}

*GHP: Geothermal Heat Pump; **ASHP: Air Source Heat Pump

On one hand, typical values for heating and cooling COP of geothermal heat pump are 4.4 and 5.6, respectively [5]. On the other hand, typical values of heating and cooling COP of air source heat pump are 3.6 and 2.8, respectively [6]. Figure 6 shows the expected monthly cooling and heating electrical energy consumption.

\subsection{Determine wells requirements}

Given that the heating and cooling COP are 4.4 and 5.6, the heating and cooling loads are 130 and $136 \mathrm{~kW}$, respectively. The maximum heat power extracted from the ground by the groundwater is $\sim 100 \mathrm{~kW}$ (power from the groundwater minus power from the compressor at the heat pump). On the other hand, the maximum heat dissipated into the ground by the groundwater is $\sim 160 \mathrm{~kW}$ (power from the building plus power from the compressor at the heat pump). The temperature difference between pumping and reinjection groundwater that the heat pump uses for functioning is $5^{\circ} \mathrm{C}$. Finally, as the water heat capacity is $\sim 4.18 \mathrm{~kW} /$ $\mathrm{kg}^{\circ} \mathrm{C}$, the maximum pumping/rejecting rate is $5 \mathrm{lt} / \mathrm{s}$ and $8 \mathrm{lt} / \mathrm{s}$ for heating and cooling, respectively.

Statistics from the Chilean Directorate General of Water (Dirección General de Aguas, DGA) indicates that wells located close to the Faculty pump more than $10 \mathrm{lt} / \mathrm{s}$. Therefore, one pumping well and one rejection well is enough for the open loop of the GHP. 


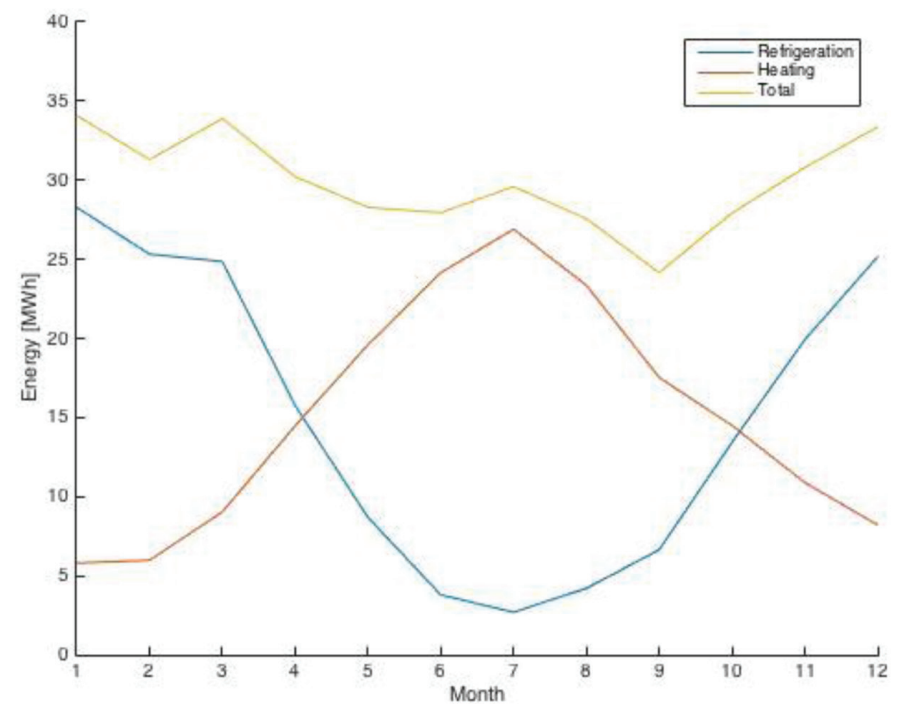

Figure 6: monthly cooling (blue) and heating (red) electrical energy consumption for aircondition with Geothermal Heat Pump (average of the years 2012-2015).

\section{COMPARISON OF AEROTHERMAL AND GEOTHERMAL SYSTEMS}

In this section, a comparison of aerothermal and geothermal systems is performed. In addition, a preliminary economic evaluation, taking into account differences between the initial investment of geothermal heat pump and air source heat pump. Also, an analysis of the savings in operation cost is presented.

\subsection{Comparison of aerothermal and geothermal systems}

The main difference between geothermal heat pump and air source heat pump is the COP due to efficiency in evaporator of the heat pump. Typical values for heating and cooling COP of geothermal heat pump are 4.4 and 5.6, respectively. On the other hand, typical values of heating and cooling COP for air source heat pump are 3.6 and 2.8, respectively (6). With the above data, the main saving operation cost is due to cooling with GHP.

\subsection{Economic project evaluation}

In the present chapter, the additional initial investment for the geothermal project will be presented, along with the expected savings in energy consumption.

The initial upfront cost includes the heat pump and the well implementation, for pumping and reinjecting water. On the one hand, the pump has to be included both in the aerothermal and geothermal project designs, so it does not imply additional spending. On the other hand, the specific additional cost will be in the wells. In Santiago, this costed US\$ 85,000.

The estimated annual energy consumption of an aerothermal system is $113.54 \mathrm{MWh}$, whereas the geothermal option represents $72.47 \mathrm{MWh}$. Considering the cost of energy with the specific tariff of the Faculty of $77 \$ / \mathrm{kWh}(0.11 \mathrm{US} \$ / \mathrm{kWh})$, the expected annual saving should be US\$ 4,520. Thus, the payback of the geothermal project is estimated to be 18 years. 


\section{CONCLUSIONS}

This paper shows that higher savings are found when cooling rather than heating capabilities are used within a geothermal GHP system. The savings should increase when solar gains are included in the analyses.

Finally, the implementation of two wells might be enough to expand the infrastructure being heated and cooled at the FCFM, which might ameliorate the economic project evaluation.

\section{ACKNOWLEDGEMENTS}

This research was partially funded by the Andean Geothermal Center of Excellence (CEGA) and the Complex Engineering Systems Institute, ISCI (Project CONICYT: FB0816).

\section{REFERENCES}

[1] Lund. J.W. \& Boyd. T.L., Direct utilization of geothermal energy 2015 worldwide review. Geothermics, 60, pp. 66-93, 2016. Available at: http://www.sciencedirect.com/ science/article/pii/S037565051500156X.

https://doi.org/10.1016/j.geothermics.2015.11.004

[2] US. Department of Energy. Guide to Geothermal Heat Pumps, 2011.

[3] Self, S.J., Reddy, B.V. \& Rosen, M.A., Geothermal heat pump systems: status review and comparison with other heating options. Applied Energy, 101, pp. 341-348, 2013. Available at: http://www.sciencedirect.com/science/article/pii/S0306261912000542. https://doi.org/10.1016/j.apenergy.2012.01.048

[4] ASHRAE. Guide to fundamentals. Atlanta. USA: American Society for Heating Refrigerating and Air Conditioning Engineers, 2009.

[5] Dimplex-SI130TUR+, Catálogo bomba de calor geotérmica Dimplex SI 130TUR+, p. 4, 2017.

[6] Dimplex-LA60TUR+, Catálogo bomba de calor aerotermia Dimplex-LA60TUR+, p. 4, 2017. 